\title{
Botanikai állapotfelmérés Somogydöröcske térségében (Külső-Somogy, Hungary)
}

\author{
JUHÁSZ MAGDOLNA \\ Rippl-Rónai Megyei Hatókörü Városi Múzeum \\ H-7400 Kaposvár, Fő u. 101., e-mail: juhasz@smmi.hu
}

\begin{abstract}
JuHÁsz, M.: Botanical survey near the village Somogydöröcske (Külsö-Somogy, Hungary).

Abstract: The vegetation was investigated on loess hills and the adjoining floodplain rivulet Koppány in SW Hungary. The aim of the botanical survey was the registration of present botanical condition, as first step of landscape restoration planning. It was found, that many species of natural phytocoenosis are encountered, but overall in disturbed vegetation, not by typical coenological conditions. The remainder species of hilly forests refer early presence of xerotherm oak woods (Vicio sparsiflorae-Quercetum pubescentis), illyrian beech woods (Vicio oroboidi-Fagetum) and illyrian oak-hornbeam (Helleboro dumetorum-Carpinetum) forests. The hilly grasslands are low-natural fallows. The natural vegetation of alluvium rivulet Koppány consist of mesotrophic wet meadows, tall-sedge beds and tall-herb vegetation of floodplains.
\end{abstract}

Keywords: vegetation, flora, naturalness, social behaviour types

\section{Bevezetés}

Botanikai szempontból Külső-Somogy hazánk kevéssé kutatott tájai közé tartozik. Talán az évszázadok óta nagy területeken jellemző mezőgazdasági hasznosítás, talán az éghajlat és növényzet átmeneti jellege a legfőbb oka annak, hogy a múlt század felfedező botanikai kutatásai nagyrészt elkerülték ezt a területet. Jelen tanulmány által vizsgált térség Kelet-Külső-Somogy kistájhoz tartozik (DövÉNYı szerk., 2010), melyre különösen jellemző az átmeneti jellegből adódó sokszínüség. A táj növényföldrajzi szempontból határozottan a Dél-Dunántúl flóravidékéhez (Praeillyricum) tartozik, keleti részén azonban felerősödik a pannon jelleg és a Sió-csatornához közeledve az Alföld (Eupannonicum) határához érkezünk. Itt, keleten-északkeleten még tatárjuharos lösztölgyesek alkották a természetes növénytakarót, majd nyugat-délnyugat felé haladva egyre határozottabban jelentkeznek elöbb a kelet-balkáni, majd a nyugat-balkáni hatások. Somogydöröcske település a kistáj déli részén végighúzódó nyugat-keleti irányú vízválasztó gerinctől északra található. A vizsgált terület a településtől nyugatra nagyrészt északias kitettségű domboldalakat és a Koppány-patak völgyének rövid szakaszát foglalja magában.

A dombvidéki táj felszínét nagyrészt negyedidőszaki, felső-pleisztocén lösz borítja. Csupán helyenként bukkannak felszínre korábbi geológiai korok képződményei, eróziós folyamatoknak erősen kitett völgyekben és gerinceken, föként felsö-pannon agyagmárga. A Koppánypatak ártéri területeit holocén iszapos, homokos, kavicsos alluvium borítja (ÁdÁM, 1981; CHIKÁN, 2000; CHIKÁN
És KóKAl, 2002). Szent István 1009-ben kelt, a pécsi egyházmegye határait kijelölő okirata „Cupa aqua” néven említi, ami a völgy mocsaras jellegére utal, és csak később tűnt fel az okiratokban a „Kupa fluvius” elnevezés. A patakot részletesen először 1771-ben mérték fel és 1838-ban ásták ki a medrét, ezzel a mocsárvilág jelentős részben lecsapolásra került. A meder azonban szűk volt és idővel annyira feliszapolódott, hogy a völgy ismét mocsárrá vált. Az újbóli tisztogatására csak 1930-1933 között került sor a „Tolnamegyei Nagykoppány patak Társulat" szervezésében (KÁROLYI, 1973). Jelenleg a meder szabályozott, egyenes csatornává alakított. Éghajlati adottságait tekintve a Kárpát-medence azon részéhez tartozik Somogydöröcske környéke, ahol legnagyobb (>15\%) az alpesi-nyugat-balkáni (illír) csapadékjárási típus gyakorisága (BORHIDI 1984). Ezt egy magasabb tavaszi és egy kisebb őszi csapadékmaximum jellemzi, de a kettős csapadékmaximumot mutató évek nyara sem száraz túlságosan. Az éves csapadékmennyiség sokévi átlaga a táj magasabb részein (Magas-Somogy) 700mm körül van (SzILÁRD, 1981). Legtöbb csapadék májusban hullik. A florisztikai-növényföldrajzi beosztás szerint a terület a Kaposense flórajáráshoz tartozik, amely a természetföldrajzi értelemben vett Külső-Somogyon kívül a Tolnai-Hegyhát jelentős részét is magában foglalja. Ez a flórajárás tehát a dél-dunántúli flóravidék (Praeillyricum) része (Soó, 1960). Korábban ezt a területet Boros (1929) „Pannonico-Praeillyricum” néven különítette el. Pontosan behatárolhatóan a vizsgált területre vonatkozó botanikai adatot nem közöl a szakirodalom, de a tágabb környék tekintetében szórványos botanikai adatok vannak. Első lényeges közlés FEKETE és BlATTNy (1913) erdészeti munkájában olvasható a bükk és az ezüsthárs Törökkoppány határában való előfordulásáról. További néhány adat Boros Ádámtól származik, aki kéziratos útinaplójának tanúsága szerint 1930. augusztus 31-én Somogyacsán járt (Boros 1930), ahol az enyves zsálya (Salvia glutinosa), a varázslófü (Circaea lutetiana) és a szegfübogyó (Cucubalus baccifer) előfordulását jegyezte fel. Nagyobb mennyiségü adat található HoRVÁT (1943) külső-somogyi flóraművében, Somogyacsa és Törökkoppány térségében mintegy száz taxont említ, köztük számos érdekes, a flóra alapvető vonásait tükröző fajt, mint a bókoló sás (Carex pendula), az óriás zsurló (Equisetum maximum [E. telmateia]), a magyar varfü (Knautia drymeia), a szártalan kankalin (Primula vulgaris), a májvirág (Anemone hepatica [Hepatica nobilis]), a békabogyó (Actaea spicata), a pirítógyökér (Tamus communis), a virágos kőris (Fraxinus ornus). 
A környék növényzetéröl nagy felbontású vegetációtérkép nem készült, részletes vegetációkutatás hiányában a Magyarország természetes növényzetét ábrázoló nagyléptékű vegetációtérképek (LEHMANN, 1981; ZóLYOMI, 1989 ) tévedésekkel terheltek, a területen jellemző három legnagyobb kiterjedésü növényzeti típus (illír bükkös, illír gyertyános-tölgyes, égerliget) egyáltalán nem kerül említésre ezeken a térképeken. Az elmúlt évtizedben a flóra és vegetáció kutatása ezen a vidéken is felélénkült, a tanulmányok számos új adatot közölnek (PINKE et al., 2006; Király, 2007; Bauer és Márkus 2008; Salamon-Albert És HoRvÁTH 2009). A vizsgált területen a botanikai állapotfelmérés tájrehabilitációs célú tervezés első lépéseként történt, az alapállapot regisztrálása céljából.

\section{Anyag és módszer}

A flóra és vegetáció felmérése részletes terepbejárások során történt. A vizsgálatok 2010-ben márciustól szeptemberig tartottak. Ebben az időszakban öt alkalommal kerestük fel a területet a növényzet és növényvilág felvételezése céljából. $A$ bejárások során 1:10000 méretarányú sztereografikus és 1:25000 méretarányú Gauss-Krüger topográfiai térképeket használtunk. A növényzeti térképen a vegetációs egységek határvonalainak rajzolása 2005-ben készült 1:10000 méretarányú légifelvétel segítségével történt.

A növényvilág elemzése során BoRHIDI (1993, 1995, 2003; BorHIDI és SÁNTA, 1999) munkáit vettük alapul, valamint a FLORA adatbázis (HoRVÁTH et al., 1995) adataival számoltunk. Az elemzéseket többféle szempont szerint végeztük, jelen tanulmányban a terület ökológiai állapotának jellemzésére leginkább alkalmas paraméterek vizsgálatát közöljük, így a cönológiai csoportok, a szociális magatartástípusok és a természetességi érték szerinti elemzés eredményei szerepelnek az alábbiakban. A számítások jelenléthiány alapján (csoportrészesedés szerint) történtek. A növényfajok nevezéktana SIMON (2000), az asszociációk elnevezése BoRHIDI (2003) munkáit követi.

\section{Eredmények}

A vizsgált terület a Koppány-völgy Gerézdpuszta és Somogydöröcske bekötőút közötti szakaszát, valamint a jobbparti ártérrel szomszédos dombsági területet foglalja magában. A terepbejárások során megállapítást nyert, hogy mind az ártérben mind pedig a szomszédos domboldalakon az eredeti növénytakaró mára jelentős mértékben átalakult. $A$ vizsgált terület jelentős része szántó, a művelt szántóföldek között másodlagos rétek és gyepek, felhagyott szőlők és gyümölcsösök, kisebb degradált erdőfoltok húzódnak. Természetes növénytársulások fajai fellelhetők, de mindenütt zavart növényzetben, nem a jellemző cönológiai viszonyok között.

A vegetációtérképen (1. ábra) hat kategóriát különítettünk el, ezek: ártéri rétek és nádasok (facsoportokkal), dombsági erdők és származékaik, dombsági gyepek, szántók (részben fiatal ültetvények), tanya, major (részben felhagyott). Ezek közül a három természetesebb vegetációs egységre (ártéri rétek, dombsági erdők, dombsági gyepek) vonatkozóan részletes elemzéseket készítettünk, jellemzésüket az alábbiakban ezek alapján ismertetjük.

$\mathrm{Az}$ ártéri rétek és nádasok a Koppány-patak és beérkező mellékvizeinek mentén találhatók (1. melléklet). A vízellátottságnak és a tájhasználatnak megfelelően változatos, többé-kevésbé átalakított élőhelyek, a természetesebb foltok mellett nemrég felhagyott szántók (parlagok) helyezkednek el (a csatornává alakított meder melletti kétoldali töltés is ide tartozik). A természetesebb növényzetet harmatkásás és pántlikafüves mocsári-vízparti növényzet, magassásrétek, mocsárrétek és ártéri magaskórósok alkotják. A felmérés évében igen sok volt a csapadék, amely az állományok természetességét némiképp javította. Leginkább természetes állapotban a dombok alján, a völgy szélén lévő források és erek növényzete van (2. és 3. ábra). A Koppány jobbparti árterének peremén fakadó szivárgó vizek és az ide érkező patakok olyan értékes növénytársulás fennmaradását is biztosították, mint a bugás sásos (Caricetum paniculatae). A vegetációtérképen magas természetességű növényzetként jelöltük a helyet, ahol tizenkilenc zsombékot számoltunk meg, ezeket együttesen mintegy tízezer bugás sás (Carex paniculata) egyed alkotja. A cönológiai csoportok részesedését (4. ábra; 1. táblázat) vizsgálva megállapítható, hogy az időnkénti áradás és magas talajvízállás által meghatározott lágyszárú növénytársulások (nádas, magassásos, mocsárrét és magaskórós) fajai együttesen csaknem $30 \%$-os arányban vannak jelen. A nádasok tömeges faja a nád (Phragmites australis), kisebb foltokban a pántlikafü (Phalaroides arundinacea), a vízi harmatkása (Glyceria maxima), de olyan érzékenyebb fajok is elöfordulnak, mint a halovány aszat (Cirsium oleraceum) és a sárga borkóró (Thalictrum flavum). Legnagyobb kiterjedésű nádas a Koppány balparti árterén lévő felhagyott szántón alakult ki, azonban ezen a helyen rendkívül fajszegény, egyhangú. A vegetációtérképen jelölt másik magas természetességű folt mocsárrét és magassásrét komplex, jellemző fajai a szürke aszat (Cirsium canum), a gyepes sédbúza (Deschampsia cespitosa), a réti kakukktorma (Cardamine pratensis), magasabb vízállású helyeken a mocsári sás (Carex acutiformis). A ligeterdők fás növényzetét a fehér füz (Salix alba), a törékeny füz (Salix fragilis) és a hamvas füz (Salix cinerea) képviselik, ezek a fajok elegyfaként jelen lehettek a szabályozás elötti természetes erdőben is, azonban mostani tömeges jelenlétüket az antropogén bolygatás miatt kialakult pionír helyzetnek köszönhetik. Egykor a patakot kísérő természetes erdők fő fafaja az enyves éger (Alnus glutinosa) volt, a vizsgált területen ez a fafaj jelenleg nem fordul elő. Az üde (mezofil) erdők fajait a baktopp (Aegopodium podagraria), a varázslófü (Circaea lutetiana), az erdei lórom (Rumex sanguineus), a medvetalp (Heracleum sphondylium), a salátaboglárka (Ficaria verna) képviselik, ezek a fajok jelen lehettek az egykori égerligetben vagy a kiszélesedő ártéri magas- 


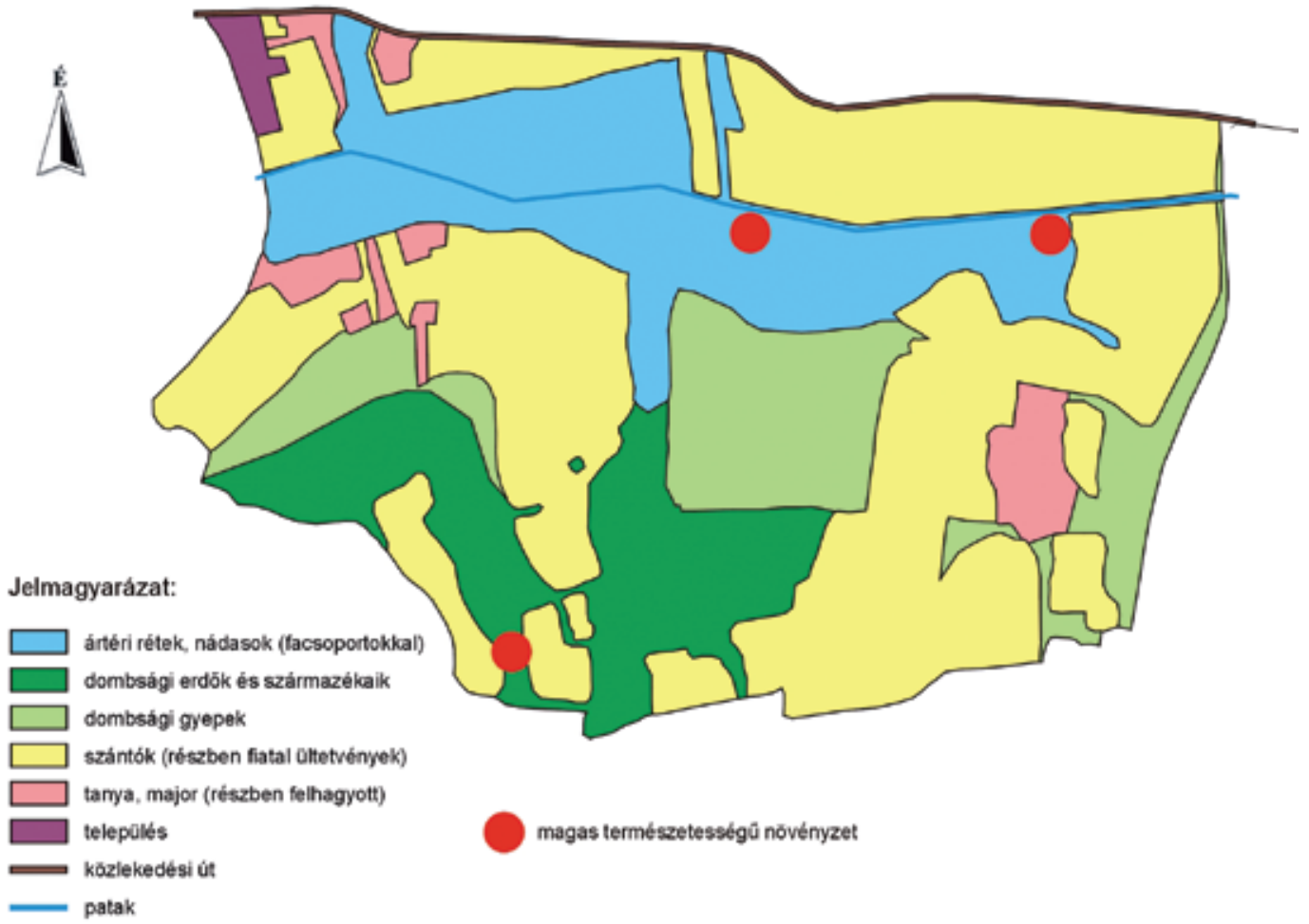

1. ábra: A vizsgált terület növényzeti térképe. (Készítette: Juhász M.)

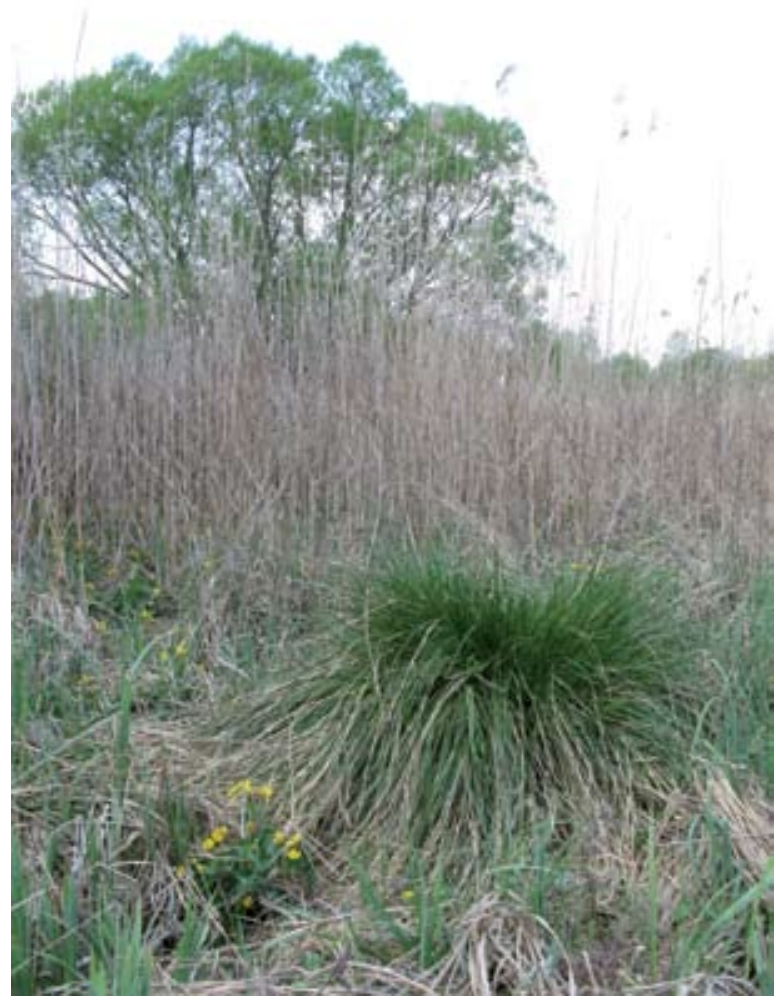

2. ábra: Háttérben nádas, elötérben a bugás sás (Carex paniculata) zsombékja. (Fotó: Juhász M.)

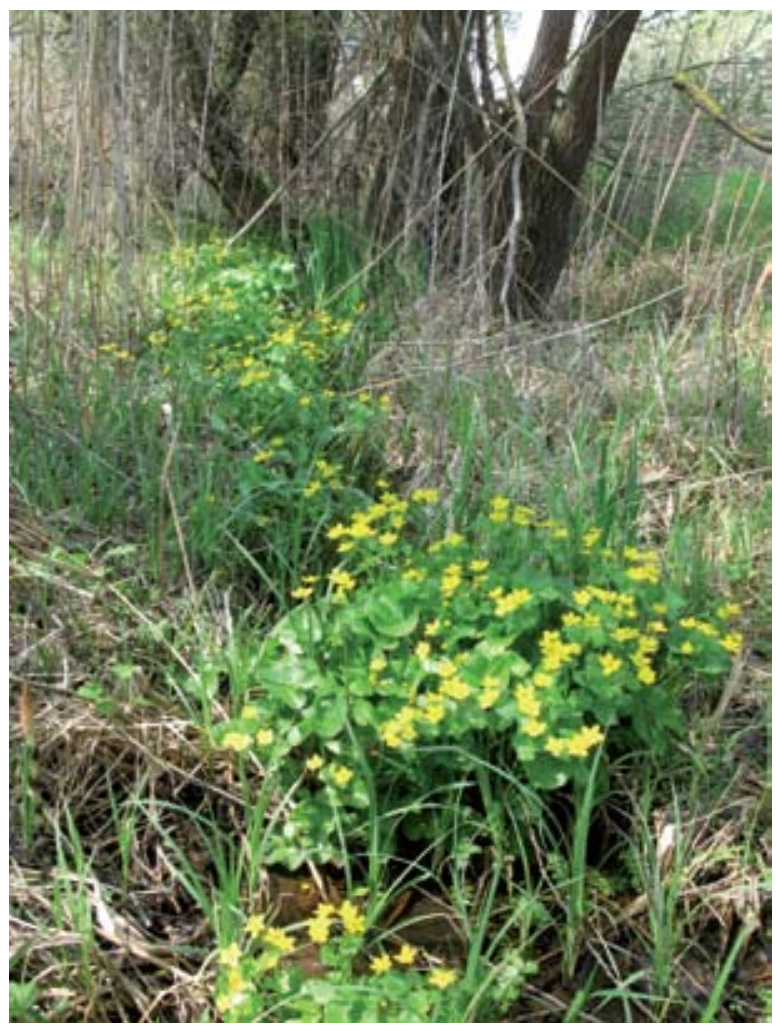

3. ábra: Virágzó mocsári gólyahír (Caltha palustris) ártéri ér vizében. (Fotó: Juhász M.) 


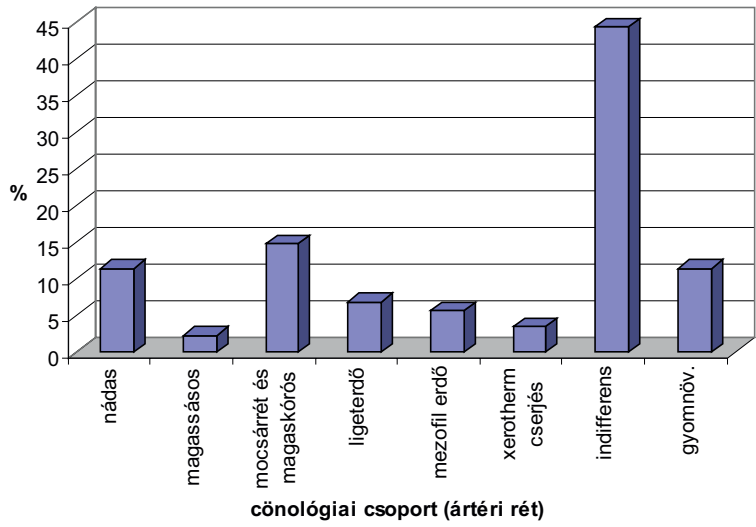

4. ábra: A fajok cönológiai karakter szerinti százalékos megoszlása az ártéri réten

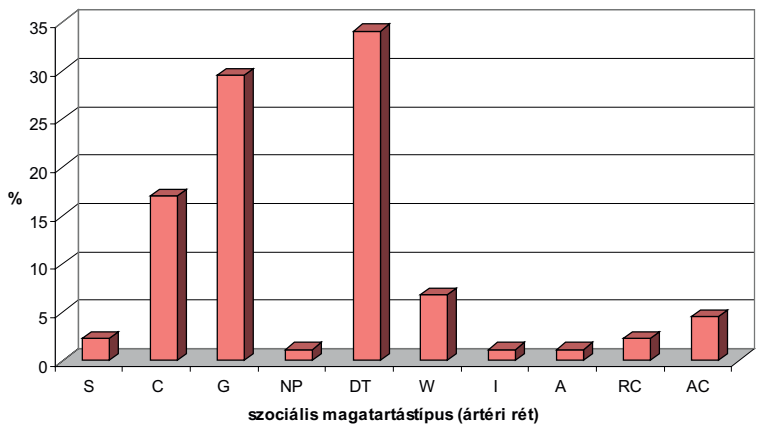

5. ábra: A fajok szociális magatartástípus szerinti százalékos megoszlása az ártéri réten

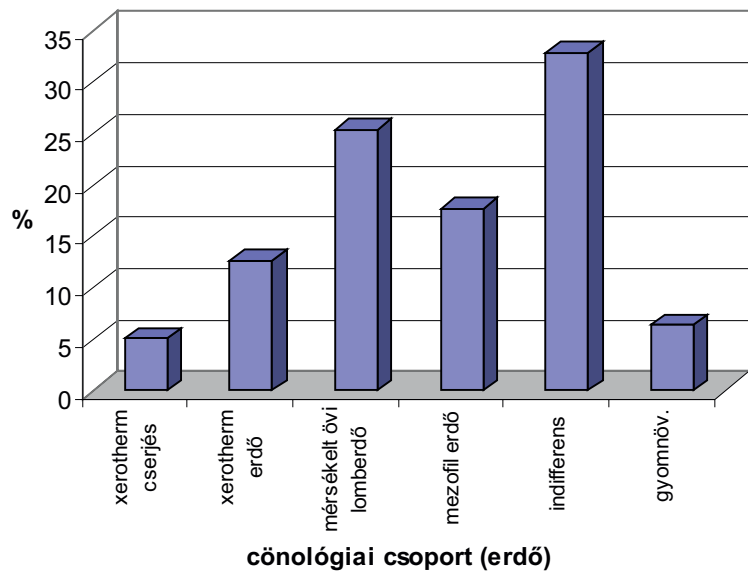

6. ábra: A fajok cönológiai karakter szerinti százalékos megoszlása a dombsági erdőben

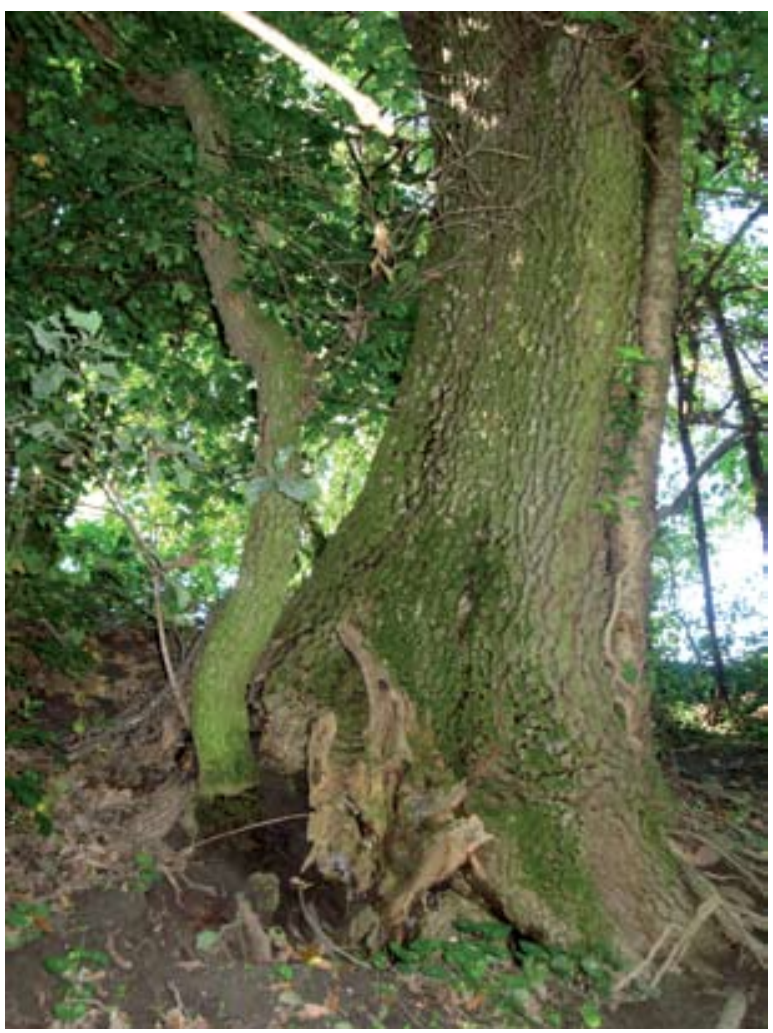

7. ábra: Molyhos tölgy (Quercus pubescens) a dombtető peremén. (Fotó: Juhász M.)

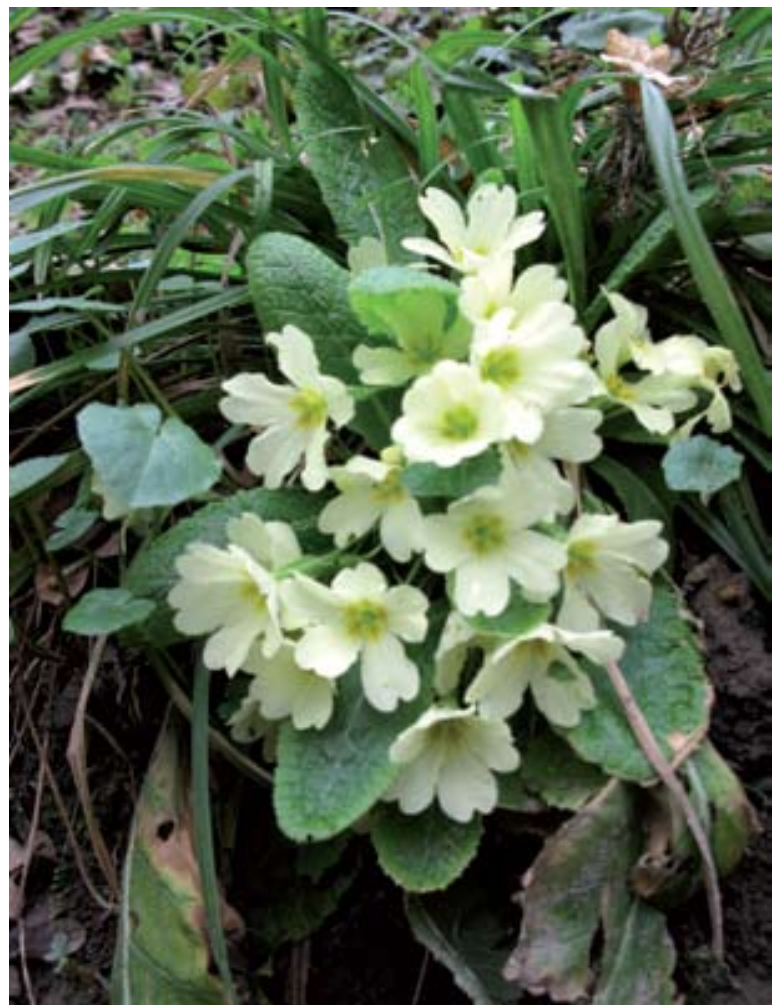

8. ábra: A szártalan kankalin (Primula vulgaris) üde erdők hírnöke. (Fotó: Juhász M.) 
latok tölgy-kőris-szil ligeterdejében is. Első pillanatra meglepő a száraz-meleg cserjések fajainak előfordulása az ártérben, ezek utak mentén, töltésen, magasabb térszintben fordulnak elő és a korábbi legeltetéssel hozhatók összefüggésbe, ilyen fajok a kökény (Prunus spinosa), a gyepürózsa (Rosa canina), a galagonya (Crataegus monogyna). Igen szembetűnő a diagramon az indifferens fajok magas részesedése, ez azonban ártéri növényzet esetében nem meglepö, hiszen a közönséges gyomjellegű fajokon (nagy csalán - Urtica dioica, mezei aszat - Cirsium arvense) kívül ebbe a csoportba tartoznak a vizes élőhelyek széles spektrumát benépesítő olyan természetes fajok is, mint a mocsári gólyahír (Caltha palustris), a pénzlevelü és közönséges lizinka (Lysimachia nummularia, L. vulgaris), a fekete nadálytő (Symphytum officinale), a mocsári tisztesfü (Stachys palustris). A szociális magatartástípusok diagramja (5. ábra; 2. táblázat) igen jól szemlélteti az ártér természetességi állapotát. A zavarástürő természetes fajok részesedése a legnagyobb (34,09\%), ebbe a csoportba a bolygatások nyomán elszaporodó honos növények tartoznak. Negatív tényező az idegenhonos fajok magas aránya, együttes részesedésük csaknem eléri a $7 \%$-ot a flórában. Tömeges megjelenésüket figyelembe véve arányuk még kedvezőtlenebb képet mutat. Legelterjedtebb inváziós faj a magas aranyvessző (Solidago gigantea), foltokban megtalálható a süntök (Echinocystis lobata), a selyemkóró (Asclepias syriaca), a seprence (Stenactis annua), de legnagyobb veszélyt az ártér természetességi állapotára a zöld juhar (Acer negundo) előfordulása jelenti. Feltűnő és igen kedvezőtlen a közönséges dió (Juglans regia) spontán szaporodása, amely a legkülönbözőbb növényzeti típusokban megjelenve szennyezi a flórát, helyenként fává növekedve gyomosító hatással van az élőhelyekre és elfoglalja az őshonos fajoktól az életteret.

Dombsági erdők és származékaik a vizsgált területnek mintegy 15 százalékán találhatók, a szántóföldnek alkalmatlan meredek domboldalban és szakadékos löszvölgyek peremén (2. melléklet). Az ártérböl mintegy 120 méter relativ magasságkülönbséggel emelkedik ki a legmagasabb hosszanti gerinc (Öreg-hegy, 251m), amely északnyugat-délkelet irányú. $A$ dombtető jelenleg is szántóként hasznosított, mellette az északkeletre néző meredek letörésen természetesebb növényzet található, az északi-északnyugati kitettségű oldal felső harmadában pedig felhagyott szölök és gyümölcsösök húzódnak. Mindezeket akácosok veszik körül és a szakadékos völgyeket is nagyrészt akácosok borítják, de a jellemző spontán erdősülés következtében őshonos fajok is mindenfelé előfordulnak. A cönológiai csoportok részesedését (6. ábra; 1 . táblázat) vizsgálva feltűnő a xeroterm erdők fajainak csaknem 13\%-os aránya. Ilyen száraz-meleg erdei élőhelyre jellemző fajok a soktérdű salamonpecsét (Polygonatum odoratum), a bársonyos tüdőfü (Pulmonaria mollis), a bablevelü varjúháj (Sedum maximum), a toronyszál (Turritis glabra), az ostorménfa (Viburnum lantana), a húsos som (Cornus mas), a bibircses kecskerágó (Euonymus verrucosa), a molyhos tölgy (Quercus pubescens, 7. ábra), a vi- rágos kőris (Fraxinus ornus). Ezek a fajok az északkeletre néző meredek letörésen csoportosulnak, ezt a helyet a vegetációtérképen magas természetességü növényzetként jelöltük. Egykor a keskeny dombtetőt melegkedvelő tölgyes (Vicio sparsiflorae-Quercetum pubescentis) borította, mely Külső-Somogy hasonló adottságú termőhelyeinek jellemző zonális erdőtársulása. Mellette az északias kitettségü domboldalban illír bükkös (Vicio oroboidi-Fagetum) és illír gyertyános-tölgyes (Helleboro dumetorum-Carpinetum) alkotta a természetes növénytakarót, ezek kiterjedésének területi aránya csak részletesebb vizsgálatok alapján rekonstruálható. Feltehetően a bükkösök voltak meghatározóak, hasonló termőhelyeken a vizsgált területtől néhány kilométerre nyugatra és keletre jelenleg is bükkösök találhatók. $A z M=1: 20000$ topográfiai térkép szerint a vizsgált dombsági terület nagy része a Hamu-dűlőhöz tartozik, ez az elnevezés is az egykori, bükkfával kapcsolatos hamuzsírfőzésre enged következtetni. Mivel az itteni bükkösök éghajlati határhelyzetben vannak, extrazonálisan északias kitettségben helyezkednek el, a csapadékmennyiség sokévi átlaga és a páratartalom éppen csak hogy elegendő számukra, ezért az antropogén eredetű bolygatásra és ennek következtében létrejövő mikroklímatikus változásra rendkívül érzékenyen reagálnak és a bükkös fajok helyét hamar a zavarástürő közönséges fajok veszik át. Ennek ellenére a bükkösökben és gyertyános-tölgyesekben élő Fagetalia fajok csaknem 18\%-os részesedéssel szerepelnek a jelenlegi flórában, a lágyszárú növények közül ilyen például a magyar varfü (Knautia drymeia), a szártalan kankalin (Primula vulgaris, 8. ábra), az enyves zsálya (Salvia glutinosa), az erdei tisztesfü (Stachys sylvatica), az orvosi tüdőfü (Pulmonaria officinalis), a zsidócseresznye (Physalis alkekengi), a fák közül pedig a hegyi juhar (Acer pseudoplatanus) és a gyertyán (Carpinus betulus). Számos képviselője megtalálható tehát az eredeti erdei flórának, még a termőhely karakterét leginkább mutató, szűkebb ökológiai türőképességü fajokból is van jónéhány. Mellettük persze többségben vannak a szélesebb elterjedésū, általános lomberdei fajok $(25,32 \%)$, mint a baracklevelü harangvirág (Campanula persicifolia), az erdei ibolya (Viola sylvestris), az erdei iszalag (Clematis vitalba), a csíkos kecskerágó (Euonymus europaea) a mezei juhar (Acer campestre), a kocsánytalan tölgy (Quercus petraea) és a dél-dunántúli erdőkben oly jellegzetes, pannon-balkáni elterjedésű ezüsthárs (Tilia tomentosa) (9. ábra). A tájhasználatra tekintettel érthető módon igen magas az indifferens fajok részesedése $(32,91 \%)$, ezek többsége gyomjellegü, és csak kevés a széles elterjedésű közönséges faj, utóbbiak közé tartozik az erdei szálkaperje (Brachypodium sylvaticum), a veresgyürü som (Cornus sanguinea), a méreggyilok (Vincetoxicum hirundinaria). A fajok szociális magatartástípusok szerinti megoszlását (10. ábra; 2. táblázat) vizsgálva megállapítható, hogy legmagasabb arányban a természetes növénytársulások tág ökológiai türőképességü fajai $(39,24 \%)$ találhatók, második legnagyobb részesedéssel a természetes zavarástü- 
rők szerepelnek $(26,58 \%)$. Az igen érzékeny specialisták $(6,33 \%)$ közül a mogyorós hólyagfa (Staphylea pinnata), a madárcseresznye (Cerasus avium), a változó boglárka (Ranunculus auricomus) előfordulását kell kiemelni. Nagyon magas az idegenhonos fajok aránya, együttes részvételük a flórában meghaladja a 10\%-ot, ezen belül a kivadult haszonnövények 3,80\%-kal, az inváziós fajok pedig 6,33\%-kal részesednek. A dombsági erdők természetességi állapotára legnagyobb veszélyt a bálványfa (Ailanthus altissima) jelenti, de nagy területi előfordulása miatt az akác (Robinia pseudoacacia) hasonlóan negativ szerepet játszik. További inváziós fajok a parlagfü (Ambrosia artemisiifolia), a magas aranyvessző (Solidago gigantea), a seprence (Stenactis annua). Kivadult haszonnövények közül a fehér eper (Morus alba), a közönséges dió (Juglans regia), a keleti ostorfa (Celtis occidentalis) fordul elö, mindhárom faj esetében mérsékelt spontán terjedés figyelhető meg.

Dombsági gyepek a vizsgált területnek mintegy $10 \%$-át teszik ki (3. melléklet). Az $M=1: 10000$ topográfiai térkép 1970-72-ben készült felmérése szerint kivétel nélkül szántóföldek voltak, tehát felhagyott szántók, azaz parlagok. Ennek ismeretében nem meglepő az indifferens fajok meghatározó szerepe (11. ábra; 1. táblázat), részesedésük a dombsági gyepek flórájában az $50 \%$-ot is meghaladja. Néhány széles elterjedésű közönséges fajt azért érdemes kiemelni, mint a füzlevelü peremizs (Inula salicina), a szarvaskerep (Lotus corniculatus), a tejoltó és a közönséges galaj (Galium verum, G. mollugo), a méreggyilok (Vincetoxicum hirundinaria) és az apróbojtorján (Agrimonia eupatoria). A termőhelynek megfelelően második legnagyobb részesedéssel a mezofil rétek fajai szerepelnek $(22,64 \%)$, mint amilyen a tarajos cincor (Cynosurus cristatus), a terebélyes harangvirág (Campanula patula), a réti imola (Centaurea jacea), a réti ecsetpázsit (Alopecurus pratensis), a franciaperje (Arrhenatherum elatius) és a mezei cickafark (Achillea collina). Valamivel kisebb az aránya a szárazgyepi fajoknak (15,09\%), jellemző képviselőik a vajszínü ördögszem (Scabiosa ochroleuca), a sátorozó margitvirág (Chrysanthemum leucanthemum), a borzas peremizs (Inula hirta), a mezei zsálya (Salvia pratensis). Szociális magatartástípusok tekintetében (12. ábra; 2. táblázat), a vizsgált növényzeti típusok közül itt a legmagasabb a természetes zavarástürő fajok aránya (43,40\%). Gyomnövények előfordulása kétszerese a dombsági erdőben vagy az ártéri réten tapasztaltnak. Némiképp megnyugtató azonban az idegenhonos fajok viszonylag alacsony részesedése $(3,77 \%)$, terepi tapasztalat alapján a jelenlévő fajok (parlagfü - Ambrosia artemisiifolia, seprence - Stenactis annua) tömegessége sem szembetűnő. Van remény tehát a gyep (13. ábra) természetességi állapotának javulására, azonban a fajkészlet gyarapodása várhatóan hosszú időt vesz igénybe, mivel természetesebb gyepfoltok a közelben nem találhatók.

\section{Megvitatás}

A Koppány-patak árterének természetes növényzetét a hajdani természetes vízjárás idején nagyrészt égerligetek (Carici pendulae-Alnetum) alkották, melyek mélyebb térszintben égeres mocsárerdőkkel (Angelico sylvestri-Alnetum) és magassás-rétekkel (Caricetum acutiformis, stb.) mozaikoltak. Kiszélesedő völgyszakaszok magasártéri szintjében keményfás ártéri erdő (Knautio drymeiae-Ulmetum) fragmentumok is elöfordultak. Az ártérrel szomszédos domboldalakban északias kitettségben illír bükkösök (Vicio oroboidiFagetum), dombhátakon és egyéb égtáji kitettségekben nyugat-balkáni típusú gyertyános-tölgyesek (Helleboro dumetorum-Carpinetum) alkották a természetes növénytakarót. A dombságból kiemelkedő keskeny gerinceken - mint Külső-Somogyban mindenütt - melegkedvelö tölgyes (Vicio sparsiflorae-Quercetum pubescentis) állományok alakultak ki. A Koppány-ártér vizsgált szakaszán és a szomszédos domboldalakban mára a növénytakaró jelentős mértékben átalakult. Eredeti természetes erdőtársulások már nem lelhetők fel, csak az időnkénti áradás és magas talajvízállás által meghatározott lágyszárú növénytársulásoknak vannak töredékes előfordulásai. A növényzet számára a víz meghatározó ökológiai tényező, a meder szabályozása és az ártér jelentős mértékű bolygatása ellenére, megfelelő vízellátás esetén a vízhez kötött társulások egy része újból kialakul. A bolygatás mértékével azonban rendszerint fordítottan arányos a fajkészlet, ismétlődő vagy intenzív beavatkozás hatására az érzékenyebb fajok eltűnnek, az ártér fajokban elszegényedik, természetességi állapota romlik (14. és 15. ábra). Más a helyzet a zsombékoló bugássásos (Caricetum paniculatae) esetében, ez a víz oxigén- és tápanyagtartalmára, áramlási viszonyaira igen érzékeny, megóvása csak a termőhely mindenfajta zavarástól való megvédése esetén lehetséges. Patakok szabályozása, halastavak létesítése, vízszennyezések következtében országszerte aktuálisan veszélyeztetett ez a növénytársulás (BoRHIDI és SÁNTA Szerk. 1999). A vizsgált szakaszon az ártér védett növényfaja a bugás sás (Carex paniculata) és az ártéri magaskórós élőhelyhez kapcsolódó örménygyökér (Inula helenium).

Természetes erdőtársulások nincsenek a vizsgált területen, a "dombsági erdők és származékaik" néven felvett vegetációtípus részben akácos, részben leginkább az "őshonos lombos fafajokkal elegyes idegenhonos lombos és vegyes erdők" (BöLöNI et al. szerk. 2010) típusával azonosítható. Az eredeti erdei flórának számos képviselője megtalálható azonban, melyek hiteles tanúi az egykor itt élt természetes erdőtársulásoknak. Igen sok érzékeny erdei növényfaj maradt fenn a vizsgált területen, ez egyrészt az extenzív tájhasználatnak, másrészt a másodlagos szukcessziós folyamatok spontán jellegének, harmadrészt pedig a természetes erdők közelségének köszönhető. Így a dombtető melegkedvelő tölgyesének hírmondói a soktérdű salamonpecsét (Polygonatum odoratum), a bársonyos tüdőfü (Pulmonaria mollis), a bablevelü varjúháj (Sedum ma- 


\section{(KÜLSÖ-SOMOGY, HUNGARY)}

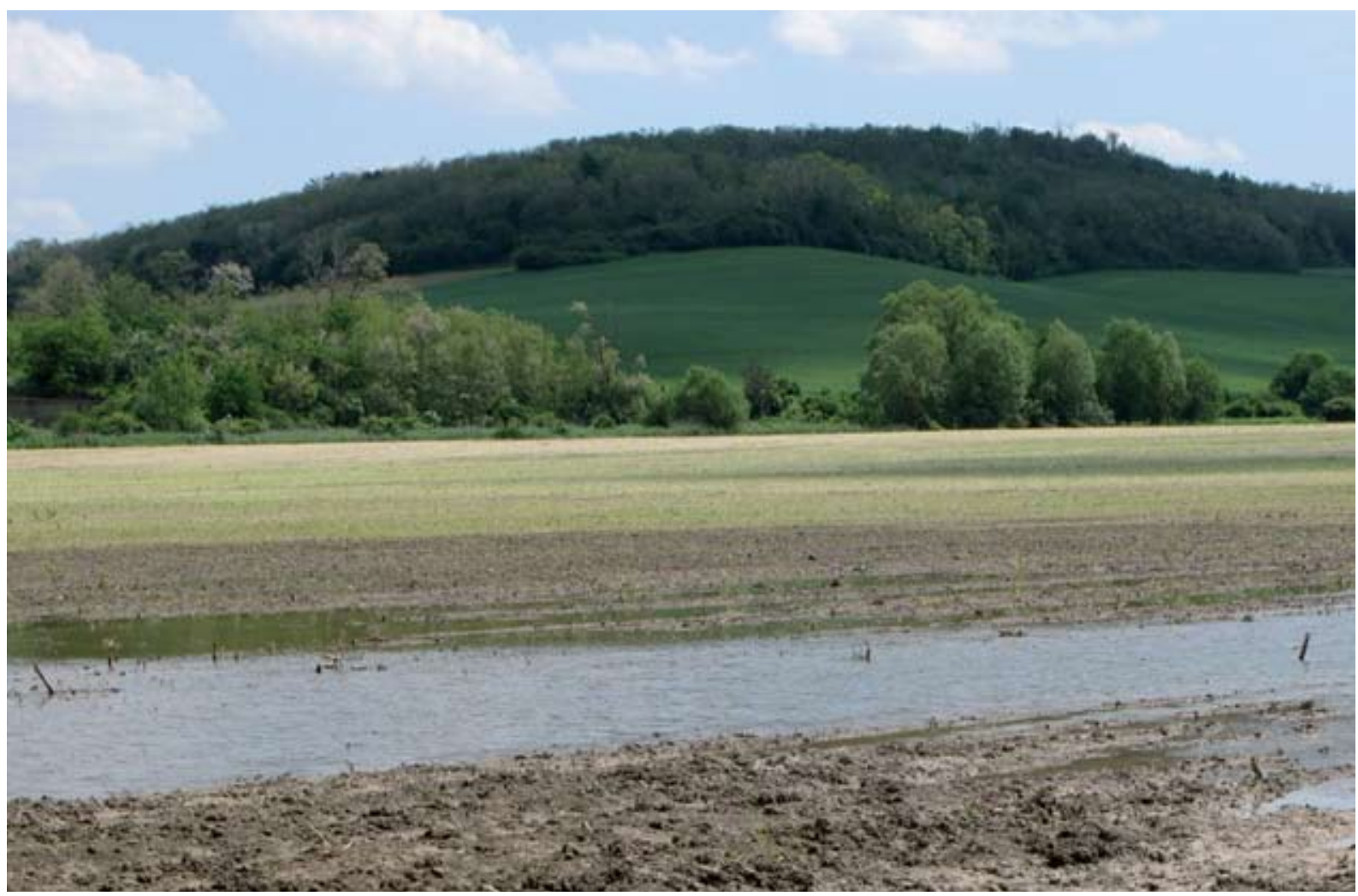

9. ábra: Dombsági erdő a Koppány-völgyböl nézve. (Fotó: Juhász M.)

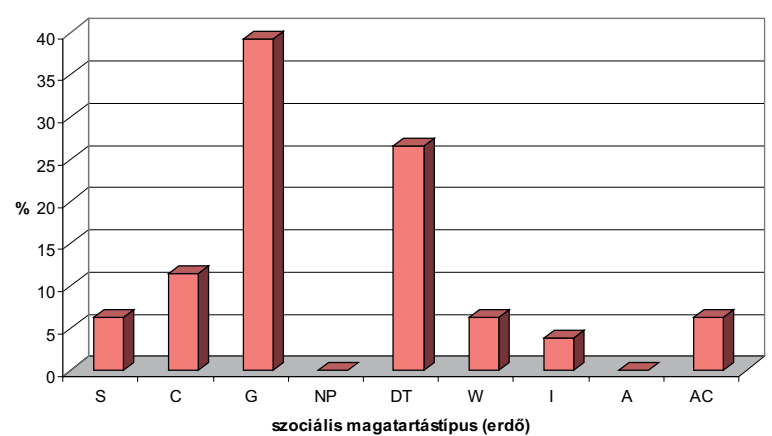

10. ábra: A fajok szociális magatartástípus szerinti százalékos megoszlása a dombsági erdőben

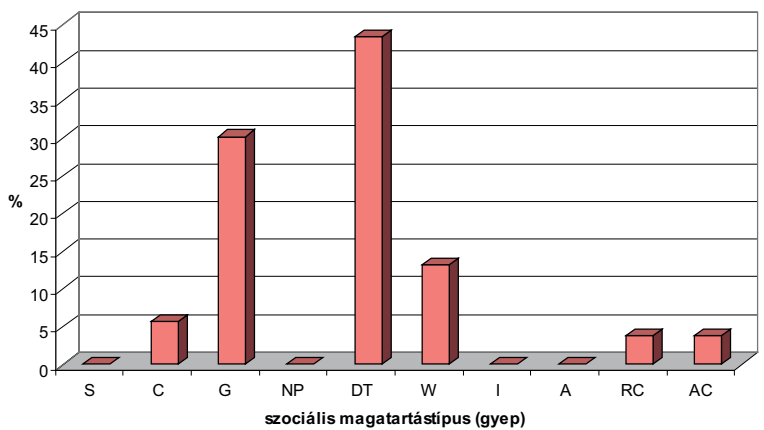

12. ábra: A fajok szociális magatartástipus szerinti százalékos megoszlása a dombsági gyepben

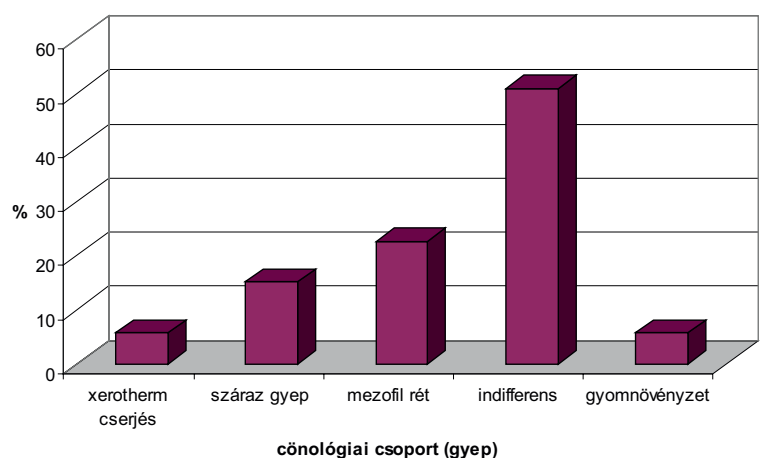

11. ábra: A fajok cönológiai karakter szerinti százalékos megoszlása a dombsági gyepben

ximum), a toronyszál (Turritis glabra), az ostorménfa (Viburnum lantana), a húsos som (Cornus mas), a bibircses kecskerágó (Euonymus verrucosa), a molyhos tölgy (Quercus pubescens), a virágos kőris (Fraxinus ornus). A domboldal illír bükkösének és gyertyánostölgyesének értékes maradványfaja a magyar varfü (Knautia drymeia), az enyves zsálya (Salvia glutinosa), az erdei tisztesfü (Stachys sylvatica), az orvosi tüdőfü (Pulmonaria officinalis) és a védett szártalan kankalin (Primula vulgaris). Az erdők természetességi állapotának javítása inváziós fafajok (bálványfa, akác) irtásával valósítható meg, azonban az ilyen irányú beavatkozások során igen körültekintően kell eljárni, a természetes 


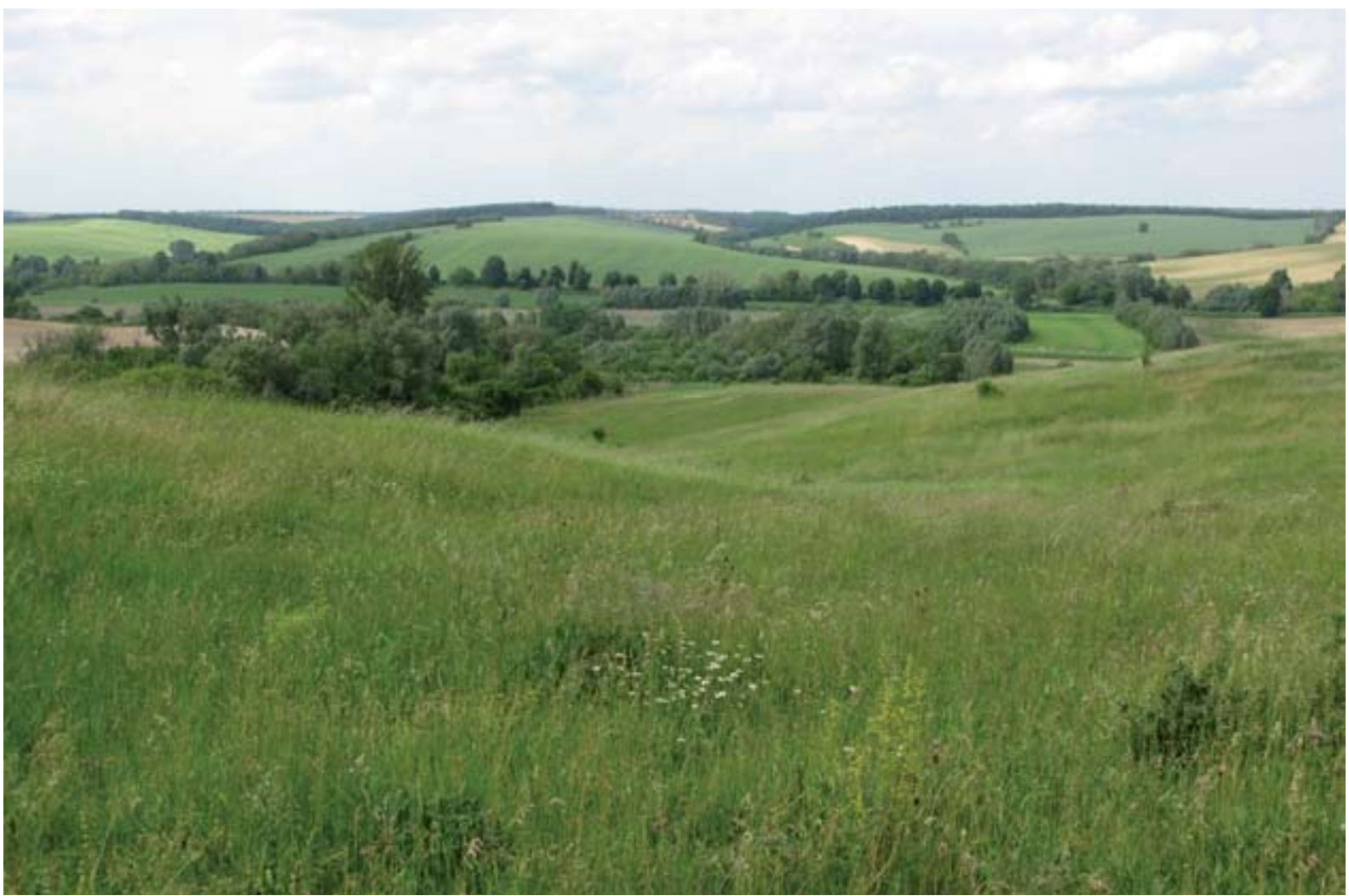

13. ábra: Dombsági gyep, háttérben a Koppány balparti dombsági táj. (Fotó: Juhász M.)

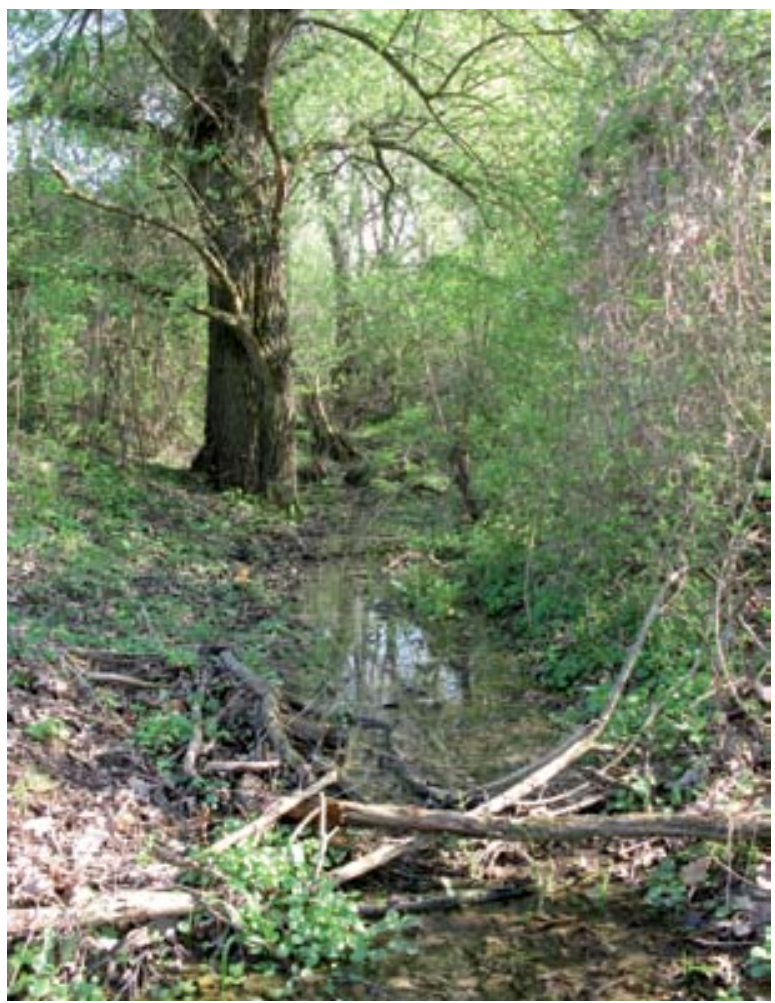

14. ábra: Ártéri ér menti természetszerü növényzet. (Fotó: Juhász M.)

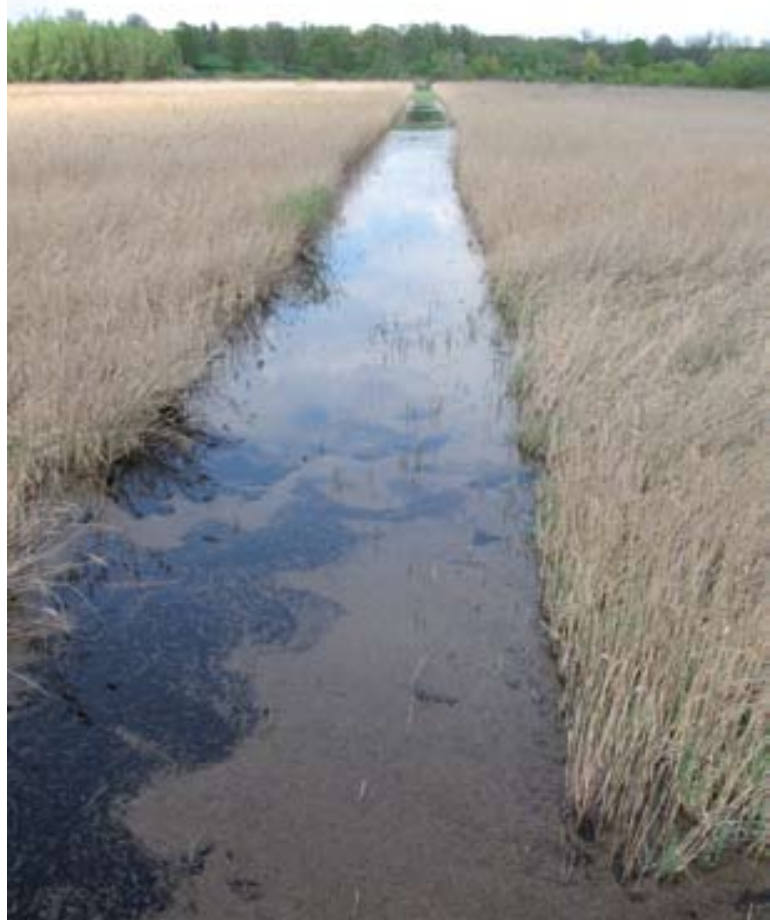

15. ábra: Felhagyott szántón kialakult fajszegény nádas. (Fotó: Juhász M.) 
(KÜLSÖ-SOMOGY, HUNGARY)

1. táblázat: A fajok cönológiai csoport szerinti százalékos megoszlása az ártéri réten, a dombsági erdőben és dombsági gyepben

\begin{tabular}{|l|r|r|r|}
\hline cönológiai csoport (COENOLB) & $\begin{array}{c}\text { ártéri rét } \\
\mathbf{( \% )}\end{array}$ & $\begin{array}{c}\text { dombsági } \\
\text { erdö (\%) }\end{array}$ & $\begin{array}{c}\text { dombsági } \\
\text { gyep (\%) }\end{array}$ \\
\hline nádas & 11,36 & & \\
\hline magassásos & 2,27 & & \\
\hline mocsárrét és magaskórós & 14,77 & & \\
\hline ligeterdő & 6,82 & & \\
\hline mezofil erdő & 5,68 & 17,72 & \\
\hline mérsékelt övi lomberdő & & 25,32 & \\
\hline xeroterm erdő & 3,41 & 12,66 & \\
\hline xeroterm cserjés & & 5,06 & 5,66 \\
\hline száraz gyep & & & 15,09 \\
\hline mezofil rét & 44,32 & 32,91 & 5,64 \\
\hline indifferens & 11,36 & 6,33 & 5,66 \\
\hline gyomnövényzet & 100,00 & 100,00 & 100,00 \\
\hline \multicolumn{1}{|c|}{ összesen } & & &
\end{tabular}

2. táblázat: A fajok szociális magatartástípus szerinti százalékos megoszlása az ártéri réten, a dombsági erdőben és dombsági gyepben

\begin{tabular}{|l|r|r|r|}
\hline $\begin{array}{c}\text { szociális magatartástípus } \\
\text { (SBT) }\end{array}$ & $\begin{array}{c}\text { ártéri rét } \\
\text { (\%) }\end{array}$ & $\begin{array}{c}\text { dombsági } \\
\text { erdö (\%) }\end{array}$ & $\begin{array}{c}\text { dombsági } \\
\text { gyep (\%) }\end{array}$ \\
\hline Specialista (S) & 2,27 & 6,33 & 0,00 \\
\hline Kompetítor (C) & 17,05 & 11,39 & 5,66 \\
\hline Generalista (G) & 29,55 & 39,24 & 30,19 \\
\hline Természetes pionír (NP) & 1,14 & 0,00 & 0,00 \\
\hline Zavarástürö (DT) & 34,09 & 26,58 & 43,40 \\
\hline Honos gyom (W) & 6,82 & 6,33 & 13,21 \\
\hline Kivadult haszonnövény ( I ) & 1,14 & 3,80 & 0,00 \\
\hline Adventív (A) & 1,14 & 0,00 & 0,00 \\
\hline Ruderális kompetítor (RC) & 2,27 & 0,00 & 3,77 \\
\hline Inváziós (AC) & 4,55 & 6,33 & 3,77 \\
\hline \multicolumn{1}{|c|}{ összesen } & 100,00 & 100,00 & 100,00 \\
\hline
\end{tabular}

3. táblázat: A fajok természetességi érték szerinti százalékos megoszlása az ártéri réten, a dombsági erdőben és dombsági gyepben

\begin{tabular}{|l|r|r|r|}
\hline $\begin{array}{c}\text { szociális magatartástípus } \\
\text { (SBT) }\end{array}$ & $\begin{array}{c}\text { ártéri rét } \\
(\%)\end{array}$ & $\begin{array}{c}\text { dombsági } \\
\text { erdö (\%) }\end{array}$ & $\begin{array}{c}\text { dombsági } \\
\text { gyep (\%) }\end{array}$ \\
\hline Specialista (S) & 2,27 & 6,33 & 0,00 \\
\hline Kompetítor (C) & 17,05 & 11,39 & 5,66 \\
\hline Generalista (G) & 29,55 & 39,24 & 30,19 \\
\hline Természetes pionír (NP) & 1,14 & 0,00 & 0,00 \\
\hline Zavarástürö (DT) & 34,09 & 26,58 & 43,40 \\
\hline Honos gyom (W) & 6,82 & 6,33 & 13,21 \\
\hline Kivadult haszonnövény (I) & 1,14 & 3,80 & 0,00 \\
\hline Adventív (A) & 1,14 & 0,00 & 0,00 \\
\hline Ruderális kompetítor (RC) & 2,27 & 0,00 & 3,77 \\
\hline Inváziós (AC) & 4,55 & 6,33 & 3,77 \\
\hline \multicolumn{1}{|c|}{ összesen } & 100,00 & 100,00 & 100,00 \\
\hline
\end{tabular}




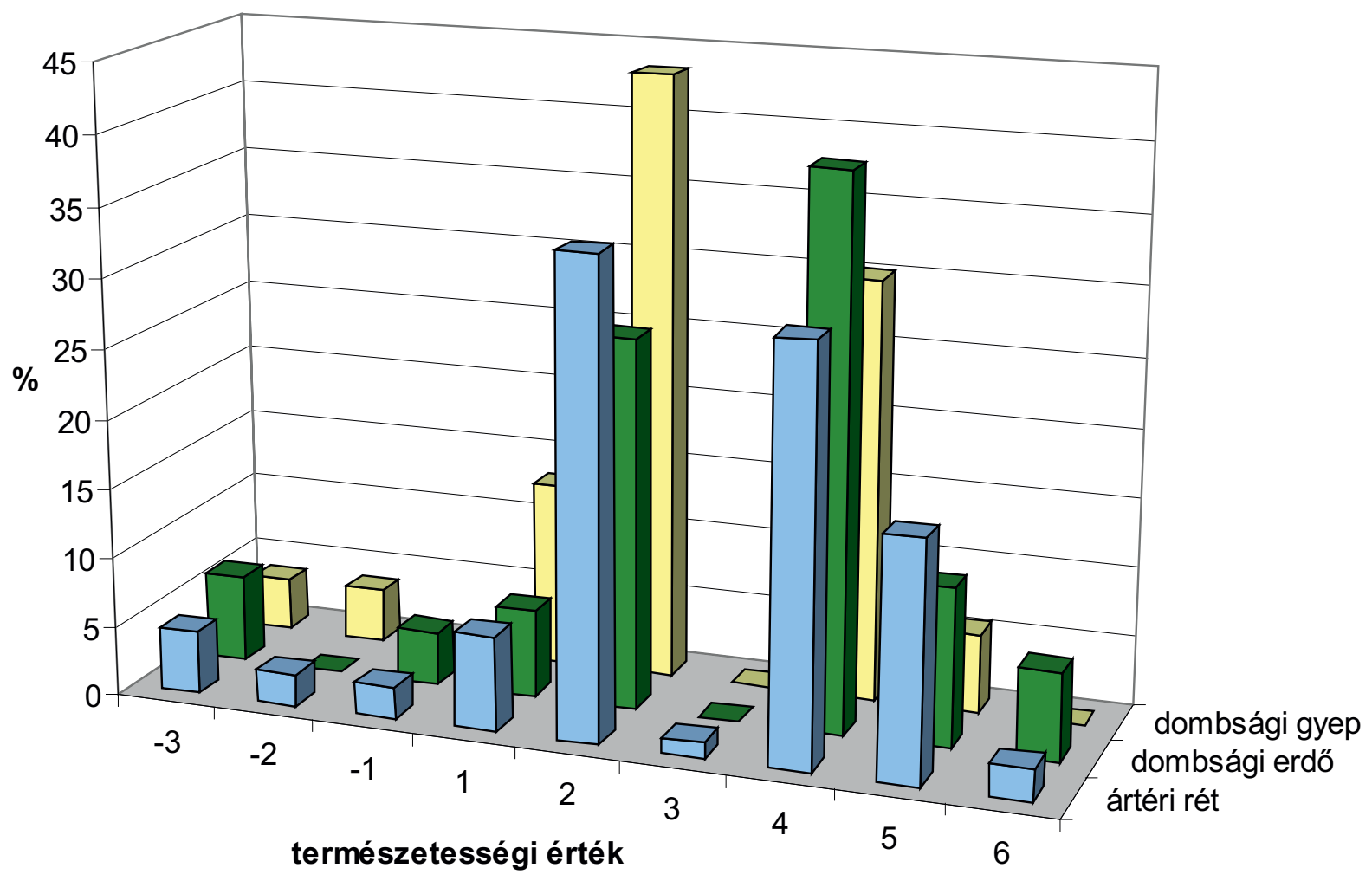

16. ábra: A fajok természetességi érték szerinti

százalékos megoszlása az ártéri réten, a dombsági erdőben és dombsági gyepben

fás- és lágyszárú növényfajoknak a termőhelyei feltétlen kímélendők. Továbbá a környezeti állapot megőrzése, javítása szempontjából alapvető jelentőségü a közelben, alig egy-két kilométeres távolságban lévő természetes erdőtársulások fennmaradása, mert azok fontos propagulum forrást jelenthetnek a másodlagos szukcessziós folyamatokban.

A növényzet és növényvilág részletes felmérése eredményeként az egyes vegetációtípusokra megszerkesztettük a természetességi értékek diagramját (16. ábra; 3. táblázat). A természetességi érték mínusz háromtól plusz tízig terjedő skáláján (BoRHIDI 1993) a térképezett növényzeti típusok fajai mínusz három és plusz hat között helyezkednek el. Figyelemre méltó, hogy mind a negatív, mind pedig a pozitív szélsőséget a dombsági erdők jelentik, tehát mind az agresszív tájidegen növények mind pedig a természetességet jelző fajok száma az erdőben a legnagyobb. Jól mutatja a diagram a dombsági gyepek általános alacsony természetességi állapotát, továbbá az ártéri termőhelyek természetesség szempontjából való változatosságát. A természetességi értékek, valamint a cönológiai csoportok és szociális magatartástípusok diagramjai szemléletesen mutatják a vizsgált terület aktuális állapotát és megfelelő alapot szolgáltatnak későbbi öszszehasonlító vizsgálatok számára.

\section{Köszönetnyilvánítás}

Köszönettel tartozom a Völgy Hangja Egyesületnek, Gelencsér Gézának és Kovács Gyulának a terület bejárásában nyújtott segítségért.

\section{Irodalom}

ÁDÁm, L. 1981: A felszíni és felszín közeli üledékek litológiai jellemzése és típusai. In: Pécsi M. (szerk.): A Dunántúli-dombság (Dél-Dunántúl). - Akadémiai Kiadó, Budapest, pp. 68-80.

Bauer N. és MÁrkus A. 2008: A Törökkoppányi erdök és a Koppánymenti rétek Natura 2000 területek botanikai értékei. - Somogyi Múzeumok Közleményei 18:51-61.

BoRHIDI A. 1984: A Zselic erdei. - Dunántúli Dolgozatok (A) Természettudományi Sorozat 4:1-145.
BORHIDI A. 1993: A magyar flóra szociális magatartás típusai, természetességi és relatív ökológiai értékszámai. (Social behaviour types of the Hungarian flora, its naturalness and relative ecological indicator values.) - Janus Pannonius Tudományegyetem Kiadványai, Pécs, $95 \mathrm{pp}$.

BORHIDI A. 1995: Social behaviour types, their naturalness and relative ecological indicator values of the higher plants of the Hungarian Flora. - Acta Botanica Hungarica 39: 97-182. 
BoRHIDI A. és SÁNTA A. (szerk.) 1999: Vörös Könyv Magyarország Növénytársulásairól 1-2. - A KöM Természetvédelmi Hivatalának Tanulmánykötetei 6. - TermészetBúvár Alapítvány Kiadó, Budapest.

BoRHIDI A. 2003: Magyarország növénytársulásai. - Akadémiai Kiadó, Budapest.

Boros Á. 1929: A Pannonicum és a Praeillyricum flóravidékek kapcsolata. - Magyar Botanikai Lapok 27:51-56.

Boros Á. 1930: Florisztikai jegyzetek XVI. - Magyar Természettudományi Múzeum, Növénytár, Budapest (kézirat)

BöLönI J., MolnÁR Zs. és Kun A. (sZERK.) 2010: Magyarország élöhelyei. ÁNÉR2010. - Magyar Tudományos Akadémia Ökológiai és Botanikai Kutatóintézete, Vácrátót (kézirat)

CHIKÁN G. 2000: Magyarország Földtani Térképe L-33-60 Kaposvár. $M=1: 100000$ - Magyar Állami Földtani Intézet, Budapest.

Chikán G. és Kókai A. 2002: Magyarország Földtani Térképe L-34-49 Dombóvár. $M=1: 100000$ - Magyar Állami Földtani Intézet, Budapest.

Fekete L. és Blattny T. 1913: Az erdészeti jelentőségü fák és cserjék elterjedése a magyar állam területén. - Selmecbánya.

HoRVÁt A. O. 1943: Külsősomogy és környékének növényzete. - A Magyar Növénytani Társaság kiadása, Budapest, Borbásia VI: $1-70$

Horváth F., Dobolyı Z., Morschhauser T., LöKös L., Karas L. és SzerDAHELYI T. 1995: FLÓRA adatbázis 1.2 Taxon-lista és attribútum állomány. - MTA Ökológiai és Botanikai Kutatóintézete és MTM Növénytár, Vácrátót - Budapest, pp. 252.
KÁROlyı Z. 1973: A Kapos és mellékvizeinek szabályozása. In: Ihrig D. (szerk.): A magyar vízszabályozás története. - Az Országos Vízügyi Hivatal kiadványa, p. 266-268.

KIRÁLY G. 2006: Kiegészítések Külső-Somogy edényes flórájának ismeretéhez. - Somogyi Múzeumok Közleményei 17:31-40.

LeHMANn A. 1981: A Dunántúli-dombság florisztikai, növényföldrajzi jellege és területbeosztása. In: Pécsi, M. (szerk.): A Dunántúli-dombság (Dél-Dunántúl). - Akadémiai Kiadó, Budapest, pp. 212-227.

MAROsı S. és Somogyı S. (szerk.) 1990: Magyarország kistájainak katasztere I-II. - Földrajztudományi Kutatóintézet, Budapest.

Pinke Gy., PÁl R., Király G. és Szendrődi V. 2006: Adatok Külső-Somogy gyomflórájának ismeretéhez. - Botanikai Közlemények 93(1-2):53-68.

Salamon-Albert, É. \& Horváth, F. 2009: Vegetation of Külső-Somogy in Hungary III. Regional diversity and pattern of abandoned fields and plant invasion. - Natura Somogyiensis 15:41-52.

Simon T. 2000: A magyarországi edényes flóra határozója. - Tankönyvkiadó, Budapest, $976 \mathrm{pp}$.

Soó R. 1960: Magyarország új florisztikai-növényföldrajzi felosztása. - MTA Biológiai Csoport Közleményei 4:43-70.

SzILÁRD J. 1981: Éghajlati adottságok. In: Pécsi M. (szerk.): A Dunántúli-dombság (Dél-Dunántúl). - Akadémiai Kiadó, Budapest, 137-169 pp.

Zólyomı B. 1989: Természetes növénytakaró. In: Magyarország Nemzeti Atlasza. - Kartográfiai Vállalat, Budapest, p.89. 
1. melléklet: Az ártéri réten élő növényfajok, azok cönológiai karaktere, szociális magatartástípusa és természetvédelmi érték számai

Acer negundo $\mathrm{L}$.

Tudományos név

Achillea collina J. Becker

Aegopodium podagraria $\mathrm{L}$.

Agrostis stolonifera L.

Alopecurus pratensis $\mathrm{L}$.

Angelica sylvestris $L$.

Arrhenatherum elatius (L.) J. et C. Presl

Asclepias syriaca $L$.

Berula erecta (Huds.) Coville

Calamagrostis epigeios (L.) Roth

Caltha palustris $L$.

Calystegia sepium (L.) R. Br.

Cardamine pratensis $\mathrm{L}$.

Carex acutiformis Ehrh

Carex gracilis Curt.

Carex hirta L.

Carex paniculata Jusl.

Carex riparia Curt.

Carex vulpina $\mathrm{L}$.

Chaerophyllum bulbosum $\mathrm{L}$.

Circaea lutetiana $\mathrm{L}$.

Cirsium arvense (L.) Scop.

Cirsium canum (L.) All.

Cirsium oleraceum (L.) Scop.

Cornus sanguinea $\mathrm{L}$.

Crataegus monogyna Jacq.

Cruciata laevipes Opiz

Cucubalus baccifer

Dactylis glomerata L. s.str.

Daucus carota L. subsp. carota

Deschampsia cespitosa (L.) P. B.

Dipsacus laciniatus $\mathrm{L}$.

Echinocystis lobata (Michx.) Torr.

Epilobium hirsutum L.

Equisetum arvense $\mathrm{L}$.

Equisetum telmateia Ehrh.

Eupatorium cannabinum L.

Ficaria verna Huds.

Galium mollugo L.

Galium verum L.

Geranium robertianum L.

Glyceria maxima (Hartm.) Holmberg s.str.

Heracleum sphondylium L.

Humulus lupulus L.

Inula helenium L.

Iris pseudacorus $\mathrm{L}$.

Juglans regia $L$.

Lamium purpureum $\mathrm{L}$.

Lathyrus pratensis $L$.

Lemna minor L.

Leontodon hispidus L.

Lychnis flos-cuculi $L$.

Lycopus europaeus L.

Lysimachia nummularia $\mathrm{L}$.

Lysimachia vulgaris $L$.

Lythrum salicaria L.

Mentha aquatica L.

Mentha longifolia (L.) Nath.

Pastinaca sativa $L$.

Phalaroides arundinacea (L.) Rauschert
COENOLB SBT

6.2.1.3

5.5

8.4 .3

Indiff.

5.4

5.4

3.5 .2

1.5.1

Indiff.

Indiff.

3.5 .2

5.4

Indiff.

1.5.1.4

Indiff.

1.5 .1

1.5.1.4

Indiff.

3.5 .2

8.4 .3

Indiff.

5.4

5.4.1

Indiff.

8.6 .1

Indiff.

8.4.3.3

Indiff.

Indiff.

5.4.1.6

3.7

3.5.2.1

Indiff.

Indiff.

8.4.3.3

Indiff.

8.4 .3

Indiff.

Indiff.

3.5 .2

1.5.1.1

8.4

Indiff.

8.4.3.3

1.5 .1

3.3

5.4

1.1.1.1

Indiff.

5.4.1

Indiff.

Indiff.

Indiff.

1.5

Indiff.

Indiff.

Indiff.

1.5 .1

5.4

5.4
1.5
Indiff

Indiff.

3.7

3.7
5.4
Indiff.

8.6 .1

5.4

Indiff.

8.6.1

Indiff.

1.5

8.4 .3
SBT WB SBT_VAL

AC $\quad 6 \quad-3$

$\begin{array}{lll}\text { DT } & 2 & 2 \\ \text { C } & 7 & 5\end{array}$

C 7

$\begin{array}{lll}C & 6 & 5\end{array}$

$\begin{array}{lll}G & 8 & 4\end{array}$

AC 4 -3

G $11 \quad 4$

RC 5 - 5

DT 9

G $\quad 8 \quad 4$

$\begin{array}{lll}\text { C } & 9 & 5 \\ \text { C } & 9 & 5\end{array}$

DT 7

C 95

$\begin{array}{lll}\text { C } & 10 & 5\end{array}$

7

G 6

RC $4 \quad-2$

G 84

G 44

G 44

DT 6

G 7

DT 6

$\begin{array}{lll}\text { C } & 7 & 5\end{array}$

$\begin{array}{lll}\mathrm{W} & 7 & 1\end{array}$

DT 9

DT $6 \quad 2$

$\begin{array}{lll}\mathrm{C} & 8 & 5\end{array}$

C 6

G 54

DT 4

C $10 \quad 5$

$\begin{array}{cll}\text { G } & 5 & 4\end{array}$

S 76

$\begin{array}{lll}G & 9 & 4 \\ I & 6 & -1\end{array}$

W 5

NP 11

DT 4

$\begin{array}{lll}\text { G } & 7 & 4\end{array}$

$\begin{array}{lll}\text { DT } & 9 \\ \text { DT } & 7\end{array}$

DT 8

G 9

$\begin{array}{lll}\text { DT } & 9 & 2\end{array}$

$\begin{array}{lll}\text { DT } & 6 & 2\end{array}$

G 9

G 5

C $10 \quad 5$

DT 4

$\begin{array}{lll}G & 6 & 4\end{array}$

DT 6

$\begin{array}{lll}\text { C } & 3 & 5\end{array}$

unculus acris $L$.

Rosa canina L. s.str.

Rubus caesius $L$.

Rumex hydrolapathum Huds.

Rumex sanguineus L. 

és természetvédelmi érték számai

Acer campestre L.

Acer pseudo-platanus $\mathrm{L}$.

Agrimonia eupatoria L.

Ailanthus altissima (Mill.) Swingle

Ajuga reptans L.

Alliaria petiolata (M. B.) Cavara et Grande

Allium scorodoprasum $\mathrm{L}$.

Ambrosia artemisifolia L.

Aristolochia clematitis L.

Artemisia vulgaris $\mathrm{L}$.

Brachypodium sylvaticum (Huds.) R. et Sch.

Campanula persicifolia L.

Carex divulsa Stokes

Carpinus betulus $\mathrm{L}$.

Celtis occidentalis L.

Cerasus avium (L.) Mönch

Chelidonium majus L.

Circaea lutetiana L.

Clematis vitalba L.

Cornus mas L.

Cornus sanguinea $\mathrm{L}$.

Corylus avellana L.

Crataegus monogyna Jacq.

Cruciata laevipes Opiz

Dipsacus laciniatus L.

Dryopteris filix-mas (L.) Schott s.str.

Euonymus europaea L.

Euonymus verrucosa Scop.

Ficaria verna Huds.

Fraxinus ornus L.

Galium aparine L.

Geranium robertianum L.

Geum urbanum L.

Glechoma hederacea L. s.str.

Hedera helix L.

Heracleum sphondylium L.

Humulus lupulus L.

Juglans regia $\mathrm{L}$.

Knautia drymeia Heuff.

Ligustrum vulgare L.

Malus sylvestris (L.) Mill.

Melica uniflora Retz

Moehringia trinervia (L.) Clairv

Morus alba $\mathrm{L}$.

Mycelis muralis (L.) Dum.

Physalis alkekengi $\mathrm{L}$.

Plantago media s.str.

Polygonatum odoratum (Mill.) Druce

Potentilla reptans $\mathrm{L}$.

Primula vulgaris Huds.

Prunus spinosa $L$.

Pulmonaria mollis Wulf.

Pulmonaria officinalis L. s.str.

Quercus cerris L.

Quercus petraea (Mattuschka) Lieblein s.str.

Quercus pubescens Willd.

Ranunculus auricomus L. s.str.

Ranunculus repens $\mathrm{L}$.

Robinia pseudo-acacia L.

Rosa canina L. s.str.

Rubus fruticosus

Rumex sanguineus $\mathrm{L}$.

Salvia glutinosa $\mathrm{L}$.

Sambucus nigra L.

Sedum maximum (L.) Hoffm

Solidago gigantea Ait. subsp. serotina (Ait.) McNeill

Stachys sylvatica L.

Staphylea pinnata L.

Stellaria media (L.) Vill.

Stenactis annua (L.) Nees

Tilia cordata Mill.

Tilia tomentosa Mönch

Turritis glabra L.

\begin{tabular}{|c|c|c|}
\hline COENOLB & SBT & SBT_VAL \\
\hline 8.4 & G & 4 \\
\hline 8.4 .3 .1 .4 & $\mathrm{~S}$ & 6 \\
\hline Indiff. & DT & 2 \\
\hline Indiff. & $A C$ & -3 \\
\hline Indiff. & DT & 2 \\
\hline Indiff. & DT & 2 \\
\hline Indiff. & DT & 2 \\
\hline Indiff. & $\mathrm{AC}$ & -3 \\
\hline Indiff. & w & 1 \\
\hline 3.5 & w & 1 \\
\hline Indiff. & G & 4 \\
\hline 8.4 & G & 4 \\
\hline Indiff. & DT & 2 \\
\hline \multirow[t]{2}{*}{8.4 .3} & C & 5 \\
\hline & I & -1 \\
\hline 8.4 .3 .2 & $\mathrm{~S}$ & 6 \\
\hline 3.5 .3 & W & 1 \\
\hline 8.4 .3 & G & 4 \\
\hline 8.4 & DT & 2 \\
\hline 8.4 .2 & G & 4 \\
\hline Indiff. & G & 4 \\
\hline 8.4 & G & 4 \\
\hline 8.6 .1 & G & 4 \\
\hline Indiff. & DT & 2 \\
\hline 3.7 & W & 1 \\
\hline 8.4 & G & 4 \\
\hline 8.4 & G & 4 \\
\hline 8.4 .2 & G & 4 \\
\hline 8.4 .3 & $\mathrm{C}$ & 5 \\
\hline 8.4 .2 .2 & $\mathrm{C}$ & 5 \\
\hline Indiff. & W & 1 \\
\hline 3.5 .2 & DT & 2 \\
\hline 6.2 & DT & 2 \\
\hline Indiff. & DT & 2 \\
\hline 8.4 & G & 4 \\
\hline 8.4 & G & 4 \\
\hline \multirow[t]{2}{*}{ Indiff. } & DT & 2 \\
\hline & 1 & -1 \\
\hline 8.4 .3 & G & 4 \\
\hline 8.4 & G & 4 \\
\hline 8.4 & G & 4 \\
\hline 8.4 & $\mathrm{C}$ & 5 \\
\hline 8.4 & DT & 2 \\
\hline 6.2 .3 & 1 & -1 \\
\hline 8.4 & G & 4 \\
\hline 8.4 .3 .3 & G & 4 \\
\hline Indiff. & DT & 2 \\
\hline 8.4 .2 & G & 4 \\
\hline Indiff. & DT & 2 \\
\hline 8.4 .3 .4 .1 & $\mathrm{~s}$ & 6 \\
\hline 8.6 .1 & C & 5 \\
\hline 8.4 .2 & G & 4 \\
\hline 8.4 .3 & G & 4 \\
\hline 8.4 .2 & C & 5 \\
\hline 8.4 & C & 5 \\
\hline 8.4 .2 & $\mathrm{C}$ & 5 \\
\hline 8.4 .3 .2 & $\mathrm{~s}$ & 6 \\
\hline Indiff. & DT & 2 \\
\hline Indiff. & $A C$ & -3 \\
\hline 8.6 .1 & DT & 2 \\
\hline Indiff. & DT & 2 \\
\hline 8.4 .3 & G & 4 \\
\hline 8.4 .3 & $\mathrm{G}$ & 4 \\
\hline Indiff. & DT & 2 \\
\hline 8.4 .2 & DT & 2 \\
\hline 3.5 & $\mathrm{AC}$ & -3 \\
\hline 8.4 .3 & G & 4 \\
\hline 8.4 .3 .2 & $\mathrm{~s}$ & 6 \\
\hline Indiff. & DT & 2 \\
\hline Indiff. & $\mathrm{AC}$ & -3 \\
\hline 8.4 & G & 4 \\
\hline 8.4 & C & 5 \\
\hline 8.4 .2 & G & 4 \\
\hline
\end{tabular}


3. melléklet: A dombsági gyepekben élő növényfajok, azok cönológiai karaktere, szociális magatartástípusa és természetvédelmi érték számai

\begin{tabular}{|c|c|c|c|}
\hline Tudományos név & COENOLB & SBT & SBT_VAL \\
\hline Achillea collina J. Becker & 5.5 & DT & 2 \\
\hline Agrimonia eupatoria L. & Indiff. & DT & 2 \\
\hline Alopecurus pratensis $\mathrm{L}$. & 5.4 & $\mathrm{C}$ & 5 \\
\hline Ambrosia artemisifolia L. & Indiff. & $\mathrm{AC}$ & -3 \\
\hline Arrhenatherum elatius (L.) J. et C. Presl & 5.4 & DT & 2 \\
\hline Bellis perennis $\mathrm{L}$. & 5.4 .2 & DT & 2 \\
\hline Campanula patula L. & 5.4 & G & 4 \\
\hline Centaurea banatica Roch. & 5.4 & G & 4 \\
\hline Centaurea jacea L. s.str. & 5.4 & G & 4 \\
\hline Cerastium glomeratum Thuill. & 5.3 .1 & G & 4 \\
\hline Chrysanthemum leucanthemum L. s.str. & 5.3 .1 & G & 4 \\
\hline Tanacetum vulgare $\mathrm{L}$. & 3.5.2.1 & W & 1 \\
\hline Cichorium intybus L. & Indiff. & W & 1 \\
\hline Coronilla varia $\mathrm{L}$. & Indiff. & DT & 2 \\
\hline Crataegus monogyna Jacq. & 8.6 .1 & G & 4 \\
\hline Crepis biennis $\mathrm{L}$. & 5.4 & DT & 2 \\
\hline Cynosurus cristatus L. & 5.4.2.3 & $\mathrm{C}$ & 5 \\
\hline Dactylis glomerata L. S.str. & Indiff. & DT & 2 \\
\hline Daucus carota L. subsp. carota & Indiff. & DT & 2 \\
\hline Dipsacus laciniatus $\mathrm{L}$. & 3.7 & W & 1 \\
\hline Festuca pratensis Huds. & Indiff. & $\mathrm{C}$ & 5 \\
\hline Galium mollugo L. & Indiff. & G & 4 \\
\hline Galium verum L. & Indiff. & DT & 2 \\
\hline Inula hirta L. & 5.3 .1 & G & 4 \\
\hline Inula salicina L. & Indiff. & G & 4 \\
\hline Chrysanthemum leucanthemum L. s.str. & 5.3 .1 & G & 4 \\
\hline Linaria vulgaris Mill. & Indiff. & w & 1 \\
\hline Linum austriacum $\mathrm{L}$. & 5.3 & G & 4 \\
\hline Lotus corniculatus L. & Indiff. & DT & 2 \\
\hline Melandrium album (Mill.) Garcke & Indiff. & W & 1 \\
\hline Mentha arvensis $\mathrm{L}$. & Indiff. & DT & 2 \\
\hline Poa pratensis L. s.str. & 5.4 & G & 4 \\
\hline Ranunculus acris $\mathrm{L}$. & 5.4 & G & 4 \\
\hline Reseda lutea $\mathrm{L}$. & 3.5 .4 & W & 1 \\
\hline Rosa canina L. s.str. & 8.6 .1 & DT & 2 \\
\hline Rumex acetosa L. & Indiff. & DT & 2 \\
\hline Salvia nemorosa $\mathrm{L}$. & 5.3 & DT & 2 \\
\hline Salvia pratensis $\mathrm{L}$. & 5.3 .1 & G & 4 \\
\hline Scabiosa ochroleuca L. & 5.3 & DT & 2 \\
\hline Stellaria graminea $\mathrm{L}$. & 5.4 & DT & 2 \\
\hline Stenactis annua (L.) Nees & Indiff. & $A C$ & -3 \\
\hline Taraxacum officinale Weber & Indiff. & $\mathrm{RC}$ & -2 \\
\hline Tragopogon orientalis $\mathrm{L}$. & Indiff. & DT & 2 \\
\hline Trifolium aureum Poll. & 8.4 .2 & G & 4 \\
\hline Trifolium pratense L. & Indiff. & DT & 2 \\
\hline Trifolium repens $\mathrm{L}$. & Indiff. & DT & 2 \\
\hline Trisetum flavescens (L.) P. B. & 5.4.2.2 & $\mathrm{s}$ & 6 \\
\hline Verbascum phlomoides $\mathrm{L}$. & Indiff. & W & 1 \\
\hline \multicolumn{2}{|c|}{ Veronica chamaedrys L. subsp. vindobonensis M. Fisodief. } & DT & 2 \\
\hline Vicia grandiflora Scop. & Indiff. & DT & 2 \\
\hline Vicia tetrasperma (L.) Schreb. & Indiff. & TZ & DT \\
\hline Vicia hirsuta (L.) S. F. Gray & Indiff. & TZ & DT \\
\hline Vincetoxicum hirundinaria Medik. & Indiff. & G & 4 \\
\hline
\end{tabular}

